\title{
1 Matthijs Siegenbeek in Defence of Dutch
}

\author{
Gijsbert Rutten
}

Honings, Rick, Gijsbert Rutten and Ton van Kalmthout (eds.), Language, Literature and the Construction of a Dutch National Identity (1780-1830). Amsterdam: Amsterdam University Press, 2018.

DOI: 10.5117/9789089648273/CHo1

\begin{abstract}
Matthijs Siegenbeek (1774-1854) was the first to hold a chair solely devoted to Dutch. While young at the time of his appointment in 1797 , he would soon occupy a central position in many cultural networks of the Netherlands. He authored the first official spelling of Dutch (1804) and was one of the first historians of Dutch literature. This chapter discusses Siegenbeek's activities in the field of Dutch studies, particularly his linguistic publications. These are interpreted within the framework of cultural nationalism, and against the background of the formation of the Dutch nation-state. Throughout his career, Siegenbeek was in defence of Dutch, where Dutch should be interpreted as a cultivated, normalised, and uniform variety modelled after the written language of well-known authors, symbolically representing the Dutch nation.
\end{abstract}

Keywords: Matthijs Siegenbeek, Dutch, Dutch linguistics, cultural nationalism, linguistic nationalism

\section{Introduction}

Matthijs Siegenbeek (1774-1854), who was inaugurated as an extraordinary professor of Dutch rhetoric at the University of Leiden in 1797, has long had the reputation of being the very first professor of Dutch. When his old acquaintance Johan Hendrik van der Palm passed away in 1840, Siegenbeek published a eulogy in which he introduced himself as the 'oldest, that is, 
the first professor of Dutch language and literature in our fatherland'. Noordegraaf, however, shows that already in 1790 Everwinus Wassenbergh, who had been appointed professor of Greek at the University of Franeker in 1771, was granted the right to teach Dutch language and literature by the Franeker board of curators. ${ }^{2}$ It is unclear whether Wassenbergh actually taught these subjects in the following years, but he certainly did from 1797 onward, when the study of Dutch was officially added to his job responsibilities. When Wassenbergh passed away in 1826 , he too was honoured by Siegenbeek in a brief biography, in which Siegenbeek commemorates the fact that Wassenbergh had combined the teaching of Greek language and literature with Dutch linguistics over the past 25 years, so only from 1801 onward. ${ }^{3}$ As discussed in the introduction to this volume, even before 1790 several academic professors were involved in the teaching of Dutch at universities across the Netherlands. Vis argues that Siegenbeek was still the first to hold a chair solely devoted to Dutch. ${ }^{4}$

Whether deliberately or not, Siegenbeek actively contributed to the collective memory of himself as the first professor of Dutch. It is perhaps understandable that he is remembered as such until the present day given his prominence as a cultural agent in the first half of the nineteenth century. While very young at the time of his appointment in 1797 , he would soon occupy a central position in many cultural networks of the Netherlands. He was given the task of creating the first official spelling of Dutch, which was published in $\mathbf{1 8 0 4}$. He is remembered as an important, and in fact as one of the first historians of Dutch literature. From 1803 to 1822 , he was the secretary of the Leiden-based Maatschappij der Nederlandsche Letterkunde ('Society of Dutch Language and Literature'), one of the first

1 Siegenbeek, 1840 , pp. 4-5: 'oudste Hoogleeraar der Nederlandsche Letterkunde in ons Vaderland'. For van der Palm, see the chapter by Krol, this volume.

2 Noordegraaf, 1997.

3 Cf. Siegenbeek, s.d. [1827], p. 14: 'In de laatste vijf en twintig jaren vereenigde hij met het onderwijs der Grieksche taal en letterkunde ook dat in de Nederduitsche taalkunde, waartoe hij eene uitnemende bevoegdheid had' ('Over the past 25 years, he united, with the teaching of Greek language and literature, that in Dutch linguistics, for which he had an excellent competence'). Note that when Herman Tollius died, one of the earlier academics who taught Dutch at the university level (see the introduction to the present volume), Siegenbeek (s.d. [1822], p. 20) did mention Tollius' academic activities in the field of Dutch studies: 'Van zijne Jongelingschap zelf een vriend en kenner der Nederlandsche Letterkunde geweest zijnde, vond hij zich opgewekt tot het geven van lessen over onze Vaderlandsche Taal, welke anders te veel veronachtzaamd was, vooral op onze Akademiën' ('Having been a friend and expert of Dutch language and literature from his youth onward, he felt like teaching the language of the fatherland, which had been too strongly neglected, particularly at our academies').

4 Vis, [2004], p. 10. 
and most well-known learned societies in the Netherlands, founded in 1766, and active to the present day. From 1822 to 1847 , he was the chair of the Maatschappij. He published numerous books, essays, editions, and lectures, some of which will be discussed in the remainder of this chapter, and was an important contributor to cultural magazines such as the Werken der Bataafsche Maatschappij van Taal- en Dichtkunde ('Proceedings of the Batavian Society for Linguistics and Poetics', 1804-1810), Museum (1812-1817) and Mnemosyne (1815-1828). A quick glance at Siegenbeek's correspondence as kept in Dutch archives and libraries reveals that he occupied a central place in various partly overlapping social and cultural networks. ${ }^{5}$

In the present paper, I will discuss Siegenbeek's activities in the field of Dutch studies, focusing on the main themes in his linguistic publications (section 4). His linguistic work, though quite diverse and not as voluminous as, for example, his work on literary history, should be interpreted within the framework of cultural nationalism and should be seen against the background of the formation of the Dutch nation-state. ${ }^{6}$ Throughout his career, Siegenbeek was in defence of Dutch, where Dutch should be interpreted as a cultivated, normalised, and uniform variety modelled after the written language of well-known authors, symbolically representing the Dutch nation. There is a close connection between Siegenbeek's linguistic output and his efforts in the fields of literary history and rhetoric (section 3). I will begin, however, with a few notes on Siegenbeek's life and work (section 2).

\section{Matthijs Siegenbeek ${ }^{7}$}

Siegenbeek was born in Amsterdam on 23June 1774 in a Mennonite family. After having finished Latin school, he attended the theological seminary of the Mennonite community in Amsterdam, where he was made ordinand in 1795. He subsequently moved to Dokkum in the province of Friesland, where

5 The Leiden University Library, for example, holds letters to/from Siegenbeek by/to wellknown cultural, literary, academic and political agents such as Jeronimo de Bosch, Arie de Jager, Cornelis Felix van Maanen, Johan Hendrik van der Palm, Laurens van Santen, Meinard and Hendrik Willem Tydeman, Jan Frans Willems, to name but a few.

6 See the introduction to this volume on cultural nationalism and the nation-building processes in the decades around 1800.

7 This section is based on the entries on Siegenbeek in volume 17 (1874) of the Biographisch woordenboek der Nederlanden by A.J. van der Aa, and in volume 5 (1921) of the Nieuw Nederlandsch Biografisch Woordenboek (NNBW), edited by P.J. Molhuysen and P.J. Blok, as well as the biography by S. Muller, published in the Handelingen der jaarlijksche algemeene vergadering van de Maatschappij der Nederlandsche Letterkunde te Leiden, gehouden den 21 Junij 1855 (s.l., s.d.). 
he became the minister of the local Mennonite community. Already in 1796, however, he was contacted by Laurens van Santen, a member of the town council of Leiden and a curator of the local university, inquiring whether Siegenbeek would be interested in the newly established chair of Dutch rhetoric at Leiden University. Van Santen had had this plan at least since the fall of 1795 , when he made a similar proposal in the board of curators. ${ }^{8}$ Siegenbeek accepted the offer and on 23 September 1797, he delivered his inaugural lecture on Openbaar onderwijs in de Nederduitsche welsprekendheid ('Public education in Dutch rhetoric'), testifying to the fact that he was first and foremost appointed to improve the rhetorical competence of the students, particularly those in theology and law. In 1799, his extraordinary chair was changed into a regular chair, and the description of its theme was widened to Dutch language and literature, which included rhetoric (cf. section 3). He would remain in office until 1844, when he was 70 years old, but continued to teach sporadically until 1847 , when he celebrated his fiftieth anniversary as a university professor. He also served twice as the rector magnificus of Leiden University (1809-1810 and 1823-1824).

As was mentioned in section 1, one of Siegenbeek's most significant activities outside the university was his long-term membership of the board of the Maatschappij der Nederlandsche Letterkunde, first as its secretary for almost twenty years, then as chair for 25 years, in which capacity he was responsible for dozens of so-called levensberichten ('biographies') of deceased members of the Maatschappij. Apart from his publications on literary history, rhetoric and linguistics discussed and mentioned in the present chapter, Siegenbeek's work includes such diverse publications as a two-volume history of the University of Leiden (Geschiedenis der Leidsche Hoogeschool, 1829-1832), a translation of Longinus' essay on the sublime (Longinus over de verhevenheid, 1811), a French version of his 1826 history of Dutch literature, translated by J.H. Lebrocquy (Précis de l'histoire littéraire des Pays-bas, 1827) as well as a tragedy (Willem de Derde, Koning van Engeland, 1832). Finally, Siegenbeek was a school inspector in the province of South Holland, serving from 1815 to $185^{2}$.

\section{$3 \quad$ Literary History and Rhetoric}

Siegenbeek's activities as a historian of Dutch literature and as a teacher of rhetoric have been studied more extensively than his linguistic works.

8 Molhuysen, 1924, p. 16; Wiskerke, 1995, p. 201. 
In the present section, I will summarise recent studies of his literary and rhetorical publications in as far as they are of immediate relevance for a good understanding of Siegenbeek the linguist, the topic of section 4.

Siegenbeek's main task as the newly appointed professor of Dutch was to teach Dutch rhetoric to university students, particularly, though not exclusively, to the next generation of ministers and lawyers in the faculties of theology and law. Not uncommon for the eighteenth and nineteenth centuries, the concept of welsprekendheid ('rhetoric') that Siegenbeek adopted encompassed the study of language and literature. ${ }^{9}$ Siegenbeek, in need of study materials, used both classical sources such as Longinus and Quintilian, but also the works of the well-known Scottish professor of rhetoric at Edinburgh, Hugh Blair, whose focus on style as a crucial part of his so-called belletristic approach to rhetoric was by and large adopted by Siegenbeek. ${ }^{10}$ The study of language and literature was part of Siegenbeek's style-oriented approach to rhetoric. In lecture notes made by students kept in the University Library in Leiden, Siegenbeek always stresses the importance of a preceding analysis of the grammar of Dutch, as well as of the Dutch literary and oratorical exempla that are needed to illustrate the rhetorical principles. He considered knowledge of the grammar of Dutch to be required in order to reach a high level of stylistic refinement, and examples of famous authors who had reached a high stylistic level would help students in their development. This means that Siegenbeek's rhetorical lessons began with an overview of the grammar of Dutch. ${ }^{11}$ Furthermore, he taught the history of Dutch literature focusing mainly on seventeenthcentury examples representing a good style and a good taste. ${ }^{12}$ Based on his courses at Leiden University, Siegenbeek published a history of Dutch literature. ${ }^{13}$ His rhetorical lessons have survived in the aforementioned lecture notes. ${ }^{14}$

In another set of lecture notes, Siegenbeek said that his lessons deserve 'the name of Lessons in Dutch rhetoric in as far as they are specifically

9 Vis, [2004], pp. 43-44.

10 Sjoer, 1996, pp. 61-63, 169-18o.

11 Sjoer, 1996, pp. 169-170.

12 Sjoer, 1996, p. 175; Vis, [2004], pp 43-46.

13 See Siegenbeek, 1826.

14 The Leiden University Library holds, for example, a manuscript called Lessen over de Nederduitsche welsprekendheid ('Lessons in Dutch rhetoric'), counting 133 pages on grammar and 277 pages on rhetoric (signature LTK 137), as well as a manuscript called Lessen over den Nederduitschen stijl ('Lessons in Dutch style'), counting 292 pages (LTK 136). Cf. Sjoer, 1996, pp. 169-170. 
organised to train the Dutchman in the rhetoric of his mother tongue', ${ }^{15} \mathrm{a}$ phrase which also occurs in other lecture notes. ${ }^{16}$ With this preliminary remark, Siegenbeek showed that he was well aware of the fact that the sheer existence of his dedicated chair should be interpreted in the ideological light of the Batavian revolution, which means that the chair was a cultural tool in the ideological construction of a united and homogeneous Dutch nation. ${ }^{17}$ In this context, the aforementioned Laurens van Santen has been called a vurig unitaris ('fiery unitarist, advocate of a centralised Dutch nation-state'). ${ }^{18}$ After having stated the general goal of his lecture, Siegenbeek explained the interrelatedness of rhetoric with the study of language and literature as follows, claiming that rhetoric encompassed

in my view, in the first place an explanation of the nature, firmness and extensiveness of our mother tongue. After all, an accurate linguistic knowledge is without any doubt the foundation of rhetoric. This is all the more necessary with respect to our language, because it is extremely carelessly spoken and written by many, being learnt through usage only, and hardly through the prescription of a purified grammar, and because the neglect of the products of our oldest and most honourable writers renders unknown most of them with their full firmness and extensiveness. ${ }^{19}$

Siegenbeek thus signalled two problems that had to be solved before a full introduction to Dutch rhetoric would be possible: lack of knowledge of the grammar of Dutch, and lack of knowledge of the literary tradition. He immediately added that an introduction to the grammar of Dutch and an anthology of the best writers would therefore be part of his course on rhetoric. ${ }^{20}$

15 Academische voorlezingen s.d., p. 2: 'deze lessen [...] den naam van Lessen over de Nederduitsche Welsprekenheid geven, voor zo verre zy byzonderlyk ingericht zyn om den Nederlander tot Welsprekenheid in zyne Moeder Taal opteleiden'.

16 Sjoer, 1996, p. 170.

17 Honings, 2011, p. 156; cf. Wiskerke, 1995, pp. 201-203.

18 In the entry on Siegenbeek in the $N N B W$, see footnote 4.

19 Academische voorlezingen, s.d., pp. 5-6: 'behoort daartoe myn 's inzien 's, in de eerste plaats eene Ontvouwinge van de Eigenschap, kracht en uitgebreidheid onzer Moeder Sprake. Immers is eene naauwkeurige Taalkennis buiten tegenspraak de grondslag der Welsprekenheid. - dit is met betrekking tot onze Taal des te noodzakelyker, omdat zy door 't gebruik alleen, zelden door het voorschrift eener gezuiverde Spraakkunst geleert wordende, door veelen ten uitersten onachtzaam gesproken \& geschreven wordt en de verwaarlozing van de voortbrengselen onzer oudste \& Achtbaarste Schryveren, de meeste met hare volle Kracht \& uitgebreidheid onbekend doet blyven'.

20 Academische Voorlezingen, s.d., p. 6. 
These concerns with the history of Dutch literature have made Siegenbeek into an important literary historian. Usually, his involvement in literary history is explained with reference to cultural nationalism as well. Wiskerke comments that for Siegenbeek, 'nationalism was [...] the motive for exercising his duties' as a professor of Dutch. ${ }^{21}$ The national literary history, then, as developed by Siegenbeek, also encompassed socio-political history and linguistic history, and resulted in an approved story of the rise, greatness and fall of the national culture. ${ }^{22}$ As such, Siegenbeek contributed strongly to the Dutch myth of the Golden Age, according to which the first half of the seventeenth century was a period of unprecedented, and since then unrepeated, economic and cultural excellence (cf. section 4.2 below). He considered the literature of the seventeenth-century to be the point de la perfection of Dutch literary history, in which the works of the authors P.C. Hooft (1581-1647) and Joost van den Vondel (1587-1679) played a crucial role. ${ }^{23}$ In his earlier overviews of the history of Dutch literature, made in the years 1800-1802, Siegenbeek located the beginning of the Golden Age in the early seventeenth century, with Hooft and Vondel, and let it persist up until his own days. ${ }^{24}$ In other words, he talked about the rise and flourish of Dutch literature, but not about its decay or fall. A few years later, however, in 1806, his ideas changed to what would become the traditional nineteenth-century view according to which the second half of the seventeenth century and the eighteenth century were marked by decay. This decay was not caused by the sudden absence of knowledge of genre conventions and normalised language in the period 1650-1800, which persisted, but by the lack of exceptional talents such as Hooft and Vondel instead. ${ }^{25}$ Jensen offers a political explanation of why authors such as Siegenbeek increasingly viewed the early seventeenth century as the Golden Age of Dutch literature and the subsequent period as one of decay. ${ }^{26}$ The year 1806 marks the end of Dutch independence, as the Netherlands were incorporated into the French state, which gave rise to an increase of anti-French sentiments, and which fuelled the search for a national cultural heritage of unsurpassable quality. In section 4, I will show that Siegenbeek's changing view of literary history ties in neatly with his ideas about the linguistic history of Dutch.

\footnotetext{
21 Wiskerke, 1995, p. 203 [my translation].

22 Wiskerke, 1995, pp. 199, 207-208.

23 Wiskerke, 1995, pp. 199, 208, 215-216.

24 Wiskerke, 1995, pp. 219-220.

25 Wiskerke, 1995, pp. 260-264.

26 Jensen, 2012.
} 


\section{$4 \quad$ Linguistics}

\subsection{Siegenbeek's Linguistic Heritage}

In addition to his literary and rhetorical studies, Siegenbeek also worked on Dutch linguistics. He is well-known for his 1804 landmark publication Verhandeling over de Nederduitsche spelling ('Treatise on the Dutch spelling'), the first official spelling regulation, published, as the subtitle says, in naam en op last van het Staats-bewind der Bataafsche Republiek ('published in the name of and by order of the government of the Batavian Republic'). Its counterpart was the official Nederduitsche spraakkunst 'Dutch grammar' by Pieter Weiland, which was published in $1805 .{ }^{27}$ Siegenbeek's spelling saw several reprints, for example a fourth one in 1827 , and moreover an abridged version ten dienste der scholen ('for the benefit of the schools') came out in 1805 and 1822 . At the request of the important so-called reformist society Maatschappij tot Nut van 't Algemeen ('Society for Public Advancement'), Siegenbeek wrote a Syntaxis and a Grammatica, which were published anonymously in 1810 and $1814 \cdot{ }^{28}$ For both the syntax and the grammar, Siegenbeek heavily relied on Weiland's grammar of $1805 \cdot{ }^{29}$

In the same period, Siegenbeek also wrote three extensive linguistic essays. In 1804, he published an essay discussing the question in hoever behoort de spelling der Nederduitsche taal geregeld te worden naar de welluidendheid en gemakkelijkheid der uitspraak ('to what extent should the spelling of the Dutch language be regulated according to the euphony and the ease of pronunciation'). His Betoog van den rijkdom en de voortreffelijkheid der Nederduitsche taal, en eene opgave der middelen om de toenemende verbastering van dezelve tegen te gaan ('Essay on the affluence and the excellence of the Dutch language, and statement of the means to counter its increasing corruption') came out in 1810. In 1814, Siegenbeek published an essay on het verband tusschen de taal en het volkskarakter der Nederlanderen ('the connection between the language and the national character of the Dutch').

In later years, fewer linguistic publications came out. When Johannes Kinker published a critical discussion of the 1826 Nederlandsche spraakleer ('Dutch grammar') by Willem Bilderdijk, he added a lengthy letter Siegenbeek had written to him on the same matter..$^{30} \mathrm{~A}$ few years later,

\footnotetext{
27 See Noordegraaf, this volume.

28 Noordegraaf, 1985 , pp. 227-230.

29 Noordegraaf, 1985 , pp. $232-25^{2}$.

30 Kinker, 1829, pp. 341-37o. For Kinker, see van der Wal, this volume.
} 
Siegenbeek published a short essay on 'some current corruptions of the pronunciation of the mother tongue'. ${ }^{11}$ In 1847 , the year of his retirement, he published a Lijst van woorden en uitdrukkingen met het Nederlandsch taaleigen strijdende ('List of words and expressions adverse to the Dutch idiom'). Finally, some of the lecture notes kept in manuscript form also comprise extensive linguistic parts, for example the Aantekeningen van M. Siegenbeek and the Academische voorlezingen are largely devoted to an overview of Dutch normative grammar..$^{32}$

Due to the aforementioned inherent interrelatedness of language, literature and rhetoric, Siegenbeek often also commented upon linguistic issues in publications on rhetoric and literary history, for example in his essay on the seventeenth-century poet Vondel, in his concise history of Dutch literature, and in his two inaugural lectures of the late $1790 \mathrm{os}$, when he first became an extraordinary professor, and in 1799 a full professor. ${ }^{33}$

Despite the fairly wide variety of linguistic themes discussed in Siegenbeek's works, he is first and foremost associated with and still remembered for his 1804 spelling regulation, which was part of what is generally known as the Schrijftaalregeling ('lit. written language regulation'). These official regulations for the written language, which also included Weiland's grammar, were the end point of the eighteenth-century development towards 'nationalization' of the language. ${ }^{34}$ In the first half of the eighteenth century, language planning activities were quite restricted and focused regarding their target audience and target varieties, as normative grammar was mainly meant for an elite audience of poets and ministers. ${ }^{35}$ Towards the end of the century, metalinguistic discourse was reconceptualised in nationalist terms, which led to the official national language policy at the beginning of the nineteenth century. From about 1770 onward, normative grammar was essentially national grammar, characterised by a whole different conceptualisation of the intended readership. Normative grammar became a matter of national concern ${ }^{36}$ and the idea gained ground that supposedly civilised and educated language should be the hall-mark of society as a whole, and should therefore be taught in schools.

The Schrijftaalregeling entailed the first official codification of Dutch, initiated by the minister of national education, Johan Hendrik van der

33 Siegenbeek, 1807, 1826, 1800.

34 Burke, 2004, p. 166.

35 Rutten, 2009.

36 Noordegraaf, 2004. 
Palm. Siegenbeek's spelling was officially approved of by van der Palm, after having consulted a few other eminent language experts, notably Adriaan Kluit and Meinard Tydeman. ${ }^{37}$ The Leiden University Library holds letters from Siegenbeek to Tydeman and van der Palm that accompanied parts of the spelling proposals that he sent to them for comments and approval..$^{8}$ Siegenbeek, in his turn, was one of the members of what could be called the advisory board of Weiland's grammar, along with Tydeman, Kluit and van der Palm. ${ }^{39}$

The uniform spelling promoted by the national government was founded on a limited set of principles, the most important one of which was to write in accordance with the pronunciation..$^{40}$ Intuitive as this may sound, Siegenbeek was probably well aware of many regionally and socially conditioned phonetic differences, and rephrased the principle in terms of following the most pure and most polite pronunciation, where polite refers to the language characteristic of the most polite people ${ }^{41}$ and, as Daan comments, of the region of Holland. ${ }^{42}$ Purity refers to the need to give the letters, as Siegenbeek says, the sound that characterises it, as well as to the prerequisite to pronounce all the letters that belong to a word fully and in an unmixed way. ${ }^{43}$ The latter definition along with the assumed but probably non-existent familiarity with the social dialect of the Holland elite among the average schoolteacher, who was supposed to teach the national language and its spelling, sparked off a lot of spelling pronunciations. These were immediately commented upon by language experts. ${ }^{44}$ One of these was Siegenbeek, who stumbled upon them in his profession as a school inspector, and subsequently published an essay on 'some current corruptions of the pronunciation of the mother tongue' in an educational journal. ${ }^{45}$ While it remains uncertain to what extent all the features he discussed should be considered spelling pronunciations, it is clear that some of them were, as they involved the pronunciation of silent

37 For Kluit, see van Driel \& van der Sijs, this volume. For Tydeman, see the introduction and Noordegraaf (2012).

38 The letters are from 1803 , signatures LTK 997 (to Tydeman) and LTK 1567 (to van der Palm). Siegenbeek, in the introduction to his spelling, also explained the various stages in the genesis and officialisation of the spelling (1804a, pp. 5-20).

39 Weiland, 1805 , p. VI.

40 'write as you speak', cf. Siegenbeek, 1804a, p. 13.

41 Siegenbeek, 1804a, pp. 18-19.

42 Daan, 1989, p. 199.

43 Siegenbeek, 1804a, p. 18.

44 Daan, 1989, pp. 199-200.

45 Siegenbeek, 1836. 
graphemes, or 'letters', which were only written for etymological reasons. These include the realisation of menschen ('people') as [mens $\chi \partial n]$ instead of [mensən], where $<\mathrm{ch}>$ should remain silent, and the realisation of the final vowel in duidelijk ('clear') and sterfelijk ('mortal') as [EI] instead of schwa. Siegenbeek wrote this short essay for schoolteachers who were unfamiliar with the targeted pronunciation and used spelling pronunciations instead, and ultimately, as he declared in the final sentence, ${ }^{46}$ to preserve the purity and the euphony of de Vaderlandsche taal ('the language of the fatherland').

\subsection{The Myth of the Golden Age}

Siegenbeek may count as a representative of the ardent supporters of the myth of the Golden Age. In a thoughtful overview of the concept of the Golden Age as it functions in a variety of nineteenth-century histories of Dutch literature meant for schools and/or home study, Johannes discusses the obvious problems the authors of these handbooks encountered. ${ }^{47}$ One example is the supposedly close connection between the Golden Age and Protestantism, and the prevailing image of the seventeenth century as the period of the rise of the Dutch nation as a Protestant nation. In reality, quite a few of the famous poets were Catholics, including Vondel. Another example is the general depreciation of the Early Modern chambers of rhetoric and the view of their members as frenchified poetasters, while many seventeenth-century writers such as Hooft and Vondel were in fact members of such chambers of rhetoric.

In the case of language, the problems were at least as pervasive. As Siegenbeek acknowledged in the introduction to his spelling proposal, the spelling differences between the most admired authors of the Golden Age, Hooft and Vondel, were great in many respects, and in the absence of general regulations, there were almost as many spelling systems as there were authors, and many writers presented themselves as language experts without having any authority to do so. ${ }^{48}$ The obvious linguistic differences between the Golden Age and the early nineteenth century were pointed out by Siegenbeek on various occasions, for example in his second inaugural lecture about Hooft as a poet and historian, as well as in the preface to an edition of the main historical works of $\mathrm{Hooft}^{49}$ - and this comparison did

\footnotetext{
46 Siegenbeek, 1836 , p. 53 .

47 Johannes, 2002.

48 Siegenbeek, 1804a, pp. 2-6; cf. Rutten, 2016.

49 Siegenbeek, 1800, p. 75; Siegenbeek et al., 1820, p. III.
} 
not always work out to Hooft's advantage, whose language was sometimes uncivilised, unnatural and lacking euphony. ${ }^{5}$ Nevertheless, this did not prevent Siegenbeek from setting up the Golden Age scheme, also with respect to language. In his essay on the affluence and the excellence of the Dutch language, he hailed Hooft as an author beyond compare for both the contents and the language of his works. ${ }^{51}$ In an essay on the literary merits of Vondel, he claimed that Hooft and Vondel were the first to expose den rijkdom en de schoonheid onzer moedertaal ('the affluence and the beauty of our mother tongue'). ${ }^{52}$ Similar claims are made in Siegenbeek's history of Dutch literature. ${ }^{53}$

The inherent tension outlined above was easily solved, as Siegenbeek provided hardly any concrete linguistic examples taken from Hooft and Vondel showing their linguistic perfection vis-à-vis earlier or more recent authors. He simply described their linguistic excellence in fairly abstract terms, claiming that their works stood out for their affluence and beauty. When Siegenbeek did engage with more concrete linguistic matters, as in his spelling proposal and in his lecture notes on the grammar of Dutch, he actually followed the eighteenth-century tradition of normative grammar. ${ }^{54}$ As Siegenbeek must have known, eighteenth-century metalinguistic discourse was heavily influenced by the written language of the seventeenth century, particularly by the language of Vondel and to a slightly lesser extent, of Hooft, for which reason it has been called vondelianism..$^{55}$ This means that there was an indirect link from Siegenbeek back to the seventeenth century, to the Golden Age. Nevertheless, he readily acknowledged that the eighteenth century was far more advanced than the seventeenth century in terms of linguistic normalisation, while even in his days, orthographic uniformity was still lacking, which was, of course, one of the reasons behind his spelling proposal..$^{6}$ In spite of the greater uniformity in spelling and grammar characteristic of the eighteenth century, the general claim that the Golden Age constituted the period to which nineteenth-century language users should turn remained unproblematic as it fed on the intrinsic and inseparable relationship of literature and linguistics (section 3). Vondel and Hooft were the best language users, simply because they were the best

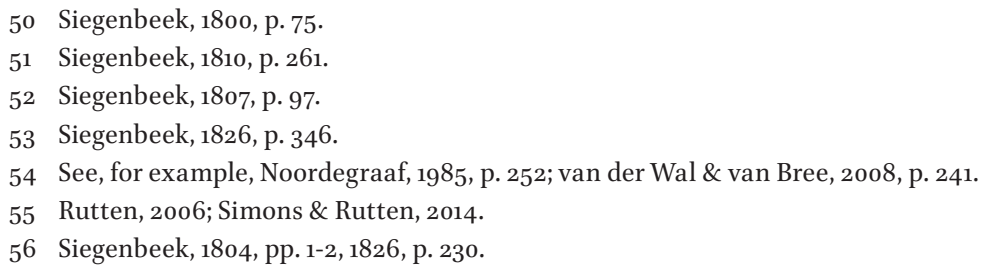


authors. In sum, the linguistic perfection of Vondel and Hooft was primarily a discursive construction relevant in the context of early nineteenth-century nationalism, and we can assume Siegenbeek was aware of this.

On many occasions, Siegenbeek referred to the revival of Dutch language and literature in the first half of the seventeenth century, identifying this period as the Golden Age and limiting himself to the abstract claim that the language of Vondel and Hooft was the best language. In one respect, however, he made the Golden Age scheme linguistically slightly more concrete. The Golden Age of Vondel and Hooft brought an end to the widespread use of loans, particularly from French. Without discussing which loans specifically were replaced by endogenous forms, Siegenbeek described the Golden Age as one of lexical purism, and Hooft and Vondel were forerunners in the purification of Dutch. ${ }^{57}$ Schematically, the impure period of the sixteenth century was succeeded by the Golden Age, which then gave way to another impure period from the second half of the seventeenth century to the late eighteenth century. The lack of purity, both before and after the Golden Age, was closely tied to the use of French loans, and the eighteenth century in particular, has often been viewed as a time of vehement frenchification. Here, the myth of the Golden Age connects with the position of Dutch as a neighbour of French and German.

\subsection{Dutch in Contact with French and German}

Johannes describes how nineteenth-century historians of Dutch literature built up the image of the Golden Age, particularly the first half of the seventeenth century, as caught between two periods of verfransing ('frenchification')..$^{8}$ Traditionally, the eighteenth century has been considered the period in which the Low Countries were heavily influenced by France, politically, socially, culturally and linguistically. The idea of the frenchified eighteenth century has been criticised in more recent times, at least from Frijhoff's seminal study onward..$^{59}$ The supposedly increasing frenchification from the second half of the seventeenth century onward created a convenient terminus ad quem for the Golden Age. In their search for a terminus a quo, literary historians proposed the second half of the sixteenth century, when a purified form of Dutch literature replaced the preceding stage characterised by Burgundian corruption and the heavily frenchified

\footnotetext{
57 Siegenbeek, 1807 , p. 96 .

58 Johannes, 2002.

59 Frijhoff, 1989.
} 
chambers of rhetoric. ${ }^{60}$ In the fourteenth and fifteenth century, large parts of the Low Countries came under Burgundian rule, and subsequently under Habsburg/Spanish rule. These political circumstances would have brought about the frenchification of Dutch language and literature, most strongly visible in the widespread use of loans, as in the poems and plays created within the various chambers of rhetoric. The Golden Age of purified Dutch from the second half of the sixteenth century to c. 1650 was more or less coterminous with the Dutch Revolt or Eighty Years' War (1568-1648), and with the political and economic success of the Dutch Republic.

Throughout Siegenbeek's work, anti-French sentiments can be found. The linguistic publication that delves deepest into the matter is the 1810 'Essay on the affluence and the excellence of the Dutch language, and statement of the means to counter its increasing corruption'. In this essay, Siegenbeek laments the general neglect of Dutch literature and the Dutch language among the Dutch people of the eighteenth and early nineteenth century, particularly among the upper ranks, who appropriate French manners and cultural products, and who prefer the French language, considering Dutch as eene plompe en boersche spraak ('a rude and lumpish language'). ${ }^{61}$ In the first chapter, he then demonstrates the affluence of Dutch by discussing its extensive lexicon, well-suited to communicate all the small nuances of human thought, and all the stylistic shades one could possibly need, which he illustrates with examples mainly taken from seventeenth-century authors. ${ }^{62}$ In addition, he argues for the morphological uniqueness of Dutch, which he considers to comprise a remarkable number of monosyllabic words, testifying to its old age, and an equally remarkable capacity to create compounds of these monosyllables. Here, Siegenbeek explicitly ties in with Grotius' views on the architecture of the Dutch lexicon, which were in turn dependent on Stevin's views. ${ }^{63}$

In the second chapter, devoted to the excellence of Dutch, Siegenbeek again discusses the old age of the language, connecting this also with a notion of purity. ${ }^{64}$ As an ancient and pure language, Dutch has kept its original lexicon comprising monosyllables as well as compounds and derivations with the accent on the original root, i.e. on the semantically most important

\footnotetext{
60 Johannes, 2002, p. 32 .

61 Siegenbeek, 1810, p. 6.

62 Siegenbeek, 1810, pp. 13-119.

63 Hugo Grotius, Parallelon rerum publicarum (manuscript c. 1602, published 1801-1803 by Johan Meermann); Simon Stévin, 'Uytspraek van de Weerdigheyt der Duytsche Tael', published in De Beghinselen der Weeghconst (1586). Cf. van der Wal (1997).

64 Siegenbeek, 1810, pp. 119-223.
} 
morpheme. As such, Dutch is said to differ sharply from French, the lexicon of which mainly consists of loans from Latin and Greek. Here, Siegenbeek again relies on Grotius, but also on early eighteenth-century linguists such as ten Kate and Huydecoper. ${ }^{65}$ In sum, Siegenbeek creates an image of the Dutch language as one that stands out for its lexical and morphological properties, which are supposedly immediately linked to its old age and purity, and which demonstrate its superiority when compared to French.

Less prominent in Siegenbeek's works are references to German, despite the fact that his grammatical works were influenced by Adelung, particularly the Umständliches Lehrgebäude der deutschen Sprache of $1782 .{ }^{66}$ In Siegenbeek's 1810 essay, the relationship between Dutch and French dominates, but German is not entirely absent. In the second chapter on the excellence of Dutch, Siegenbeek praises the euphony of Dutch consonants when compared to their German counterparts. ${ }^{6}$ In the following pairs, Dutch has voiced stops and fricatives, while German has unvoiced ones, and Siegenbeek considers voicing to be 'softer': vuil-faul 'dirty, (Gm.) rotten, lazy', vroom-fromm 'pious', moeder-Mutter 'mother', dal-Thal 'valley'. Siegenbeek also criticised the 'harsh and rude' affricate $p f$ - as in German $p f l i c h t$ 'duty'. ${ }^{6}$ Siegenbeek's 'List of words and expressions adverse to the Dutch idiom', published in 1847, predominantly comprises and criticises German loans. The apparent change of orientation from anti-French to anti-German in Siegenbeek's linguistic writings may signal wider changes in international cultural contacts and their discursive representation, and merits further investigation.

Siegenbeek's criticism of French loans and his conceptualisation of particularly the long eighteenth century as a period of frenchification is entirely traditional, and fits in well with contemporary and more recent discourses on French dominance and francophilia in this period ${ }^{69} \mathrm{Charac}-$ teristic of Siegenbeek, who was a professor of Dutch and a school inspector, is perhaps his focus on a remedy and even more so, his insistence that the supposed frenchification can be countered through mother-tongue education. After having established 'the general neglect of and contempt for the language and literature of the fatherland', which is supposed to be the result of the decreasing love of the fatherland, Siegenbeek argues that

65 Lambert ten Kate, author of Aenleiding totde kennisse van het verhevene deel der Nederduitsche sprake (1723); Balthazar Huydecoper, author of Proeve van taal- en dichtkunde (1730).

66 Noordegraaf, 1985 , pp. 235-237.

67 Siegenbeek, 1810, pp. 119-223.

68 Siegenbeek, 1810, p. 140.

69 Vogl, 2015; Rutten, Vosters \& van der Wal, 2015. 
to cure this 'evil', a new kind of mother-tongue education will be necessary in order to teach 'the polite Dutchman' knowledge of the Dutch language as well as to excite 'the spirit of love of the fatherland'..$^{\circ}$ This new kind of mother-tongue education should encompass schoolbooks with historical and literary texts, particularly from the seventeenth century, as well as anthologies of poets such as Vondel and Hooft. ${ }^{71}$ He also calls for a new purist dictionary. ${ }^{72}$

The educational solution offered by Siegenbeek in his essay on 'the means to counter the increasing corruption' of Dutch neatly ties in with his first inaugural lecture 'on public education in Dutch rhetoric'. ${ }^{73}$ This lecture has a strong apologetic undertone, reflecting Siegenbeek's position as the first professor with a chair solely devoted to the study of Dutch. Noordegraaf calls it an oratio pro domo, as Siegenbeek takes half of his lecture to explain that Dutch rhetoric is equally well possible as Greek and Latin rhetoric, illustrating this by identifying a respectable Dutch tradition including Vondel and Hooft ${ }^{74}$.

He ends his lecture by paying special attention to three societal domains that he apparently considers crucial in the context of his chair, viz. the University of Leiden, the arts and sciences generally, and finally, the fatherland..$^{75}$ The whole line of reasoning of the lecture is framed in a nationalistic discourse, indicating not only the necessity of teaching Dutch rhetoric - which encompasses both literature and linguistics, cf. section 3 - but also the advantages that an advanced level of rhetoric will have in the legal and religious domains, and above all in parliament. ${ }^{76}$ Clearly, Siegenbeek was well aware of the symbolic relevance of his academic position for the Dutch nation as an ethnic and political body.

\subsection{Language and Nation}

In 1814 , Siegenbeek published an essay 'on the connection between the language and the national character of the Dutch'. The relationship between

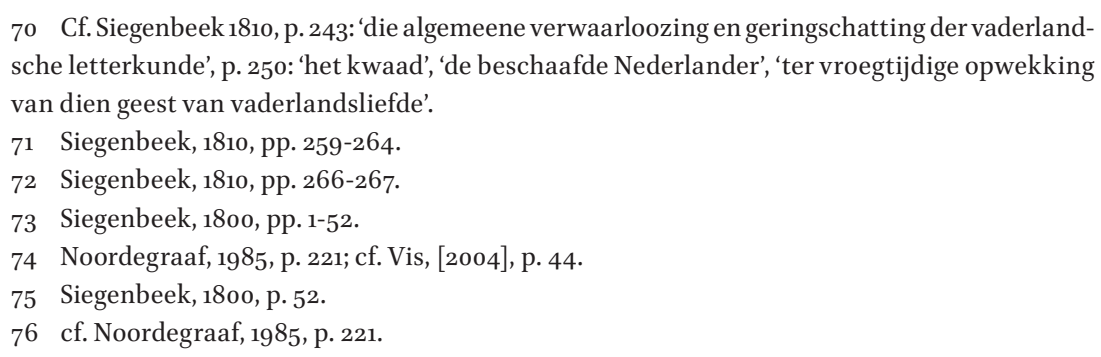


language and nation had been a common theme throughout the previous century ${ }^{77}$, and by the time Siegenbeek wrote his essay, many of his ideas had become common knowledge, including the three principles from which he developed his argument, viz. that man is primarily and uniquely defined by his language, that his language is a mirror of the soul, and that his language is also a mirror of the cognitive and moral character of the nation he is part of. ${ }^{78}$ From the third, 'Humboldtian' assumption, it follows that the basic characteristics of a nation must be strongly and significantly present in its language. ${ }^{79}$ With this 'Humboldtian' approach to the interrelationship of language and nation, Siegenbeek took up a theme well-known across eighteenth- and nineteenth-century Europe, including Germany and the Low Countries. ${ }^{80}$ The remainder of Siegenbeek's essay is devoted to an inventory of characteristics of the Dutch people, and the way in which these are represented in the Dutch language.

The first characteristic of the true and pure Dutchman is that he is calm and sensible - a myth that lives on until the present day - which is in contrast with fire and liveliness ('vuur', 'levendigheid'), but also with the frivolity and fickleness ('wuftheid, ligtzinnigheid en onbestendigheid') of the southern peoples ('de meer zuidelijk gelegene volken'). ${ }^{81}$ Here, Siegenbeek evokes an opposition of Germanic and Romance that he will return to a few times. Linguistically, the moderate character of the Dutch is reflected in the phonology of the language, which has neither too many vowels nor too many consonants. Languages that have many vowels may sound pleasantly and harmoniously, but are also a little bit too 'melting, tender, and, if I may say so, effeminate'..$^{82}$ Languages that combine too many consonants in difficult clusters 'hurt the ear with an unpleasant coarseness'. ${ }^{83}$ Dutch, then, is located between these stereotypical images of Romance and Germanic languages. In 1779, in a poetical essay, Cornelis van Engelen had contrasted

77 Cf. Rutten, 2007 for a brief overview focussed on Dutch.

78 Siegenbeek, 1814, pp. 89-90.

79 Siegenbeek 1814, p. 93: 'Het kan derhalve niet anders zijn, of ook de hoofdtrekken van het karakter van eener natie moeten in de taal, van welke zij zich, als de haar eigene en door haar zelf gevormde, bedient, krachtig en sprekend zijn ingedrukt'.

80 Noordegraaf, 1999.

81 'den echten, onverbasterden Nederlander', Siegenbeek, 1814, p. 96.

82 Siegenbeek 1814, p. 101: 'Talen, in welke klinkletters, vooral zachte en lieflijke, de overhand hebben, streelen wel het oor door eene aangename en harmonieuse opvolging van klanken; maar hebben tevens iets al te smeltends, teeders en, mag ik zeggen, verwijfds in haren toonval'. 83 Siegenbeek 1814, p. 101: 'Zulke talen daarentegen, waarin doorgaans eene vereeniging van zware en harde medeklinkers, zonder behoorlijke afwisseling van vloeijende klinkers, wordt waargenomen, kwetsen het oor door eene onaangename ruwheid'. 
the vowelly Italian with the much less vowelly German, claiming that the number of vowels and consonants determines a language's softness and hardness, respectively. ${ }^{84}$

Another characteristic of the Dutch is their sincerity and love of the truth, which strangers often mistake for rudeness and impoliteness. ${ }^{85}$ Linguistically, this characteristic is manifest in the impossibility to flatter in Dutch without overstating it. Again, this is in opposition to 'the French language of flattery, in which even the strongest expressions have lost almost all of their force as a result of their daily use'. ${ }^{86}$ Similarly, the Dutch love of independence is reflected in a relatively flexible syntax, as opposed to the French language, which has a much more fixed syntax, according to Siegenbeek. ${ }^{87}$ Siegenbeek then criticises the equally strong rules of French classicism, and adds that the free Dutch spirit has regained its independence, also in this respect. ${ }^{88}$ This remark is probably a reference to the recent defeat of Napoleon and the end of the French reign of the Low Countries, which have freed themselves from the tyranny of both French classicism and French politics.

A final characteristic of the Dutch is the moral and religious character of their language. ${ }^{89}$ Here, Siegenbeek refers to the lexicon, specifically to the absence of endogenous euphemisms for mistress, and criticizing the French for having and apparently needing such words as galant and coquette. The irony is, of course, that these words are also French loans in Dutch, indicating that the Dutch are familiar with the concepts just as well.

In his final remarks, Siegenbeek explains that the Dutch language is the essence of the Dutch nation, recalling that the foreign rulers had tried to bring this language to decay and depreciation. ${ }^{\circ}$ Here, he is probably referring to Napoleon's efforts to frenchify the administrative and legal domains, and to prescribe the teaching of French in schools. ${ }^{91}$ The French were well aware that they would never be able to fully rule the Dutch as

84 Van Engelen, 1779, p. 197.

85 Siegenbeek, 1814, p. 112 .

86 Siegenbeek 1814, p. 101: 'de Franse vleitaal, waarin ook de sterkste bewoordingen, door het dagelijksch gebruik, schier alle kracht verloren hebben'.

87 Siegenbeek, 1814, pp. 115-116.

88 Siegenbeek, 1814, p. 118: 'Niet lang echter heeft de vrije Nederlandsche geest zich door deze banden laten kluisteren, maar integendeel zijne onafhankelijkheid, ook in dit opzigt, loffelijk gehandhaafd'.

89 Siegenbeek, 1814, p. 118.

90 Siegenbeek, 1814 , p. 123 .

91 Kloek \& Mijnhardt, 2001, p. 437. 
long as the linguistic wall that kept them apart had not been broken down..$^{2}$ Tearing down this wall, would have led to 'the entire corruption of our national character', to 'the extinguishing of the final spark of love of the fatherland', and to 'the irreparable completion of our slavery and our fall'. ${ }^{3}$ He concludes by calling for intergenerational transmission of the Dutch language until the last descendants, that is, through education. ${ }^{94}$

\section{$5 \quad$ Final remarks}

In this paper, I have singled out the most important themes that can be gleaned from the various publications and manuscripts by Matthijs Siegenbeek in the field of Dutch studies, paying special attention to his linguistic works. An important preliminary observation is that for Siegenbeek, as for many of his contemporaries, linguistics, literary history and rhetoric are interconnected parts of what we now call Dutch studies. Different from present-day academic practice, Siegenbeek integrated these three domains, and argued that to focus on one necessarily implied taken into account the others.

Throughout Siegenbeek's works, the cultural nationalism is found that also inspired Laurens van Santen to create Siegenbeek's dedicated chair of Dutch. Thus, asking Siegenbeek to design the national orthography was clearly the right choice. An important theme in Siegenbeek's studies of the history of Dutch language, literature and rhetoric is the Golden Age myth, according to which the history of these fields can be told in a narrative about their rise, greatness and fall. The period of greatness was the Golden Age, situated in the first half of the seventeenth century, coinciding with the political and economic success of the Dutch Republic. The authors Vondel and Hooft represent the concomitant literary success. Linguistically, Siegenbeek's main argument to consider this period the Golden Age appears to be the interest in lexical purism, which replaced the previous love of loans from French.

In the same vein, the position of the Dutch language area close to the French and German language areas is another major theme in the work of

92 Siegenbeek, 1814, p. 124: 'zoo lang de scheidsmuur, die, in het behoud onzer tale, ons van hen verwijderde, niet geheel was omverre geworpen'.

93 Siegenbeek, 1814, p. 124: 'geheele verbastering van ons volkskarakter', ‘uitdooving ook van den laatsten vonk van vaderlandsliefde', 'onherstelbare voltooijing van onze slavernij en onzen val'. 94 Siegenbeek, 1814, p. 125: 'tot de laatste nakomelingschap'. 
Siegenbeek. Particularly the relationship with French, and the influence of French literature and of the French language on the Dutch culture is a matter of great concern, giving rise to an at times vehement anti-French discourse. A Dutch national and cultural identity is built in competition and contrast with other European cultures, and particularly the French. This also means that the Dutch culture and the Dutch language as conceptualised by Siegenbeek are homogeneous entities at the national level. There is hardly any reflection on internal linguistic variation, for example, on regional and social variation within the language area. External linguistic variation is conceptualised in terms of national languages such as Dutch and French that need to remain unmixed and pure, leaving no room for language contact. Subscribing to the well-known nationalist axiom that language and nation are intertwined, Siegenbeek moreover took the interesting effort to link the national auto-image of calmness, sincerity and religiosity to specific linguistic levels such as the phonology, syntax and lexicon of the Dutch language.

The defence of Dutch, a leitmotiv in Siegenbeek's works, can be summarised as the nationalistic effort to discursively construct a homogeneous and unmixed Dutch language, symbolising the Dutch nation, and modelled after the writings of the famous poets of the Golden Age, often in the fullest awareness of the empirical invalidity of many of the assumptions and claims involved in this effort.

\section{References}

Aantekeningen van M. Siegenbeek by de Nederduitsche spraakkunstvan P. Weiland. Manuscript University Library Leiden, LTK 49.

Academische voorlezingen over de Nederduitsche tale en welsprekenheid van den hoog geleerder heer M. Siegenbeek. Gewoon hoog leeraar in dezelven aan s lands universiteit te Leyden. $A^{\circ} 1797$ \& 1798 . Manuscript University Library Leiden, BPL 3363.

P. Burke, Languages and Communities in Early Modern Europe (Cambridge: Cambridge University Press, 2004).

J. Daan, 'Als niet komt tot iet... Nederlands van hoog tot laag', Verslagen en mededelingen van de Koninklijke Vlaamse Academie voor Nederlandse Taal- en Letterkunde (1989), 168-245.

C. van Engelen, 'Antwoord op de vraag, van de Maatschappy der Nederlandsche Letterkunde. Welke zijn de algemeene oogmerken, die een dichter moet bedoelen? Welke zijn derhalven de eigenaartige onderwerpen voor de dichtkonst? 
En welke zijn derzelver algemeene regelen?', Werken van de Maetschappy der Nederlandsche Letterkunde, 4 (1779), 63-224.

W. Frijhoff, 'Verfransing? Franse taal en Nederlandse cultuur tot in de revolutietijd', Bijdragen en mededelingen betreffende de geschiedenis der Nederlanden, 104 (1989), 592-6o9.

R. Honings, Geleerdheids zetel, Hollands roem! Het literaire leven in Leiden 1760-186o (Leiden: Primavera Pers, 2011).

L. Jensen, 'De Gouden Eeuw als ijkpunt van de nationale identiteit. Het beeld van de Gouden Eeuw in verzetsliteratuur tussen 1806 en 1813', De Zeventiende Eeuw, 28 (2012), 161-175.

G.-J. Johannes, “'Zoo is overdrijving de ziekte van elke eeuw." Het beeld van de $17 \mathrm{de}$ eeuw in 19de-eeuwse literatuurgeschiedenissen voor schoolgebruik en zelfstudie', Nederlandse Letterkunde, 7 (2002), 28-60.

J. Kinker, Beoordeeling van M. W. Bilderdijks Nederlandsche spraakleer (Amsterdam: Johannes van der Hey en zoon, 1829).

J. Kloek \& W. Mijnhardt, 180o: Blauwdrukken voor een samenleving (The Hague: Sdu, 2001).

P.C. Molhuysen, Bronnen tot de geschiedenis der Leidsche universiteit. Volume 7 (The Hague: Martinus Nijhoff, 1924).

J. Noordegraaf, Norm, geest en geschiedenis. Nederlandse taalkunde in de negentiende eeuw (Dordrecht \& Cinnaminson: Foris, 1985).

J. Noordegraaf, 'Het begin van de universitaire neerlandistiek: Franeker 1790?', in Voorlopig verleden, Taalkundige plaatsbepalingen (Münster: Nodus Publikationen, 1997), pp. 14-27.

J. Noordegraaf, 'Vaderland en moedertaal. Een constante in het taalkundig denken', in Vaderland. Een geschiedenis vanafde vijftiende eeuw tot 1940, ed. by N.C.F. van Sas (Amsterdam: Amsterdam University Press, 1999), pp. 343-363.

J. Noordegraaf, 'A Matter of Time. Dutch Philosophy of Language in the Eighteenth Century', in Janus at the Millennium. Perspectives on Time in the Culture of the Netherlands, ed. by T.F. Shannon \& J.P. Snapper (Dallas etc: University Press of America, 2004), pp. 211-225.

J. Noordegraaf, 'Over taal en maatschappij in de achttiende eeuw. Het werk van Meinard Tydeman (1741-1825)', Neerlandica Wratislaviensia, 21 (2012), 87-100.

G. Rutten, De Archimedische punten van de taalbeschouwing. Davidvan Hoogstraten (1658-1724) en de vroegmoderne taalcultuur (Amsterdam: Stichting Neerlandistiek VU \& Münster: Nodus Publikationen, 2006).

G. Rutten, 'The Nationalist turn. Dutch Linguistics and German Philosophy in the Eighteenth and Early Nineteenth Centuries', in History of Linguistics 2005, ed. by D.A. Kibbee (Amsterdam \& Philadelphia: John Benjamins, 2007), pp. 288-307. 
G. Rutten, 'Grammar to the People. The Dutch Language and the Public Sphere in the 18th Century. With Special Reference to Kornelis van der Palm', Beiträge zur Geschichte der Sprachwissenschaft, 19 (2009), 55-86.

G. Rutten, 'The Myth of the Golden Age and the Construction of Dutch as a National Language', in Metalinguistic Perspectives on Germanic Languages in Europe: Case Studies from Past to Present, ed. by G. Rutten \& K. Horner (Oxford: Peter Lang, 2016), pp. 13-39.

G. Rutten, R. Vosters \& M. van der Wal, 'Frenchification in Discourse and Practice: Loan Morphology in Dutch Private Letters of the Eighteenth and Nineteenth Centuries', in Past, Present and Future of a Language Border: Germanic-Romance Encounters in the Low Countries, ed. by C. Peersman, G. Rutten \& R. Vosters (Berlin \& New York: De Gruyter, 2015), pp. 143-169.

M. Siegenbeek, Twee redevoeringen (Leiden: L. Herdigh, 180o).

M. Siegenbeek, Verhandeling over de Nederduitsche spelling, ter bevordering van eenparigheid in dezelve, door Matthys Siegenbeek, hoogleraar in de Nederduitsche Letterkunde te Leyden: uitgegeven in naam en op last van het Staats-bewind der Bataafsche Republiek (Amsterdam: Johannes Allart, 1804a).

M. Siegenbeek, 'Antwoord op de vraag, in hoe ver behoort de spelling der Nederduitsche taal geregeld te worden naar de welluidendheid en gemakkelijkheid der uitspraak?', Werken der Bataafsche Maatschappij van Taal-en Dichtkunde, 1 (1804b), 1-108.

M. Siegenbeek, 'Verhandeling over de dichterlijke verdiensten van Joost van den Vondel', Werken der Bataafsche Maatschappij van Taal-en Dichtkunde, 2 (1807), 35-108.

M. Siegenbeek, 'Antwoord op het voorstel der Bataafsche Maatschappij van Taal- en Dichtkunde, vorderende een Betoog van den rijkdom en de voortreffelijkheid der Nederduitsche taal, en eene opgave der middelen om de toenemende verbastering van dezelve tegen te gaan', Werken der Bataafsche Maatschappij van Taal- en Dichtkunde, 5 (1810), 1-273.

M. Siegenbeek, 'Over het verband tusschen de taal en het volkskarakter der Nederlanderen', Museum, of verzameling van stukken ter bevordering van fraaije kunsten en wetenschappen, 3 (1814), 89-125.

M. Siegenbeek, [The life of Herman Tollius], Jaarboek van de Maatschappij der Nederlandse Letterkunde 1822 (S.l., s.d. [1822]), 18-32.

M. Siegenbeek, Beknopte geschiedenis der Nederlandsche letterkunde (Haarlem: Erven François Bohn, 1826).

M. Siegenbeek, [The life of Everwinus Wassenbergh],Jaarboekvan de Maatschappij der Nederlandse Letterkunde 1827 (S.l., s.d. [1827]), 11-19. 
M. Siegenbeek, 'Waarschuwing tegen eenige in zwang gebragte verbasteringen van de uitspraak onzer moedertaal', Nieuwe bijdragen ter bevordering van het onderwijs en de opvoeding (1836), 42-53.

M. Siegenbeek, Hulde aan de nagedachtenis van den hoogleeraarJ.H. van der Palm (Leiden: D. du Mortier en Zoon, 1840).

M. Siegenbeek, Lijstvan woorden en uitdrukkingen met het Nederlandsch taaleigen strijdende (Leiden: S. en J. Luchtmans, 1847).

M. Siegenbeek, A. Simons \& J.P. van Capelle (eds.), P.C. Hoofts Nederlandsche Historien. (Amsterdam: Johannes van der Hey, 1820).

T. Simons \& G. Rutten, 'Language Norms and Language Use in Eighteenth-Century Dutch. Final $n$ and the Genitive', in Norms and Usage in Language History, 160o-19oo. A Sociolinguistic and Comparative Perspective, ed. by G. Rutten, R. Vosters \& W. Vandenbussche (Amsterdam \& Philadelphia: John Benjamins, 2014), pp. 49-72.

E. Sjoer, Lessen over welsprekendheid. Een typering van de retorica's van de eerste hoogleraren in de vaderlandse welsprekendheid in de Noordelijke Nederlanden (1797-1853) (Amsterdam: IFOTT, 1996).

G.J. Vis, Van Siegenbeek tot Lodewick. Verkenningen naar de geschiedenis van de studie der Nederlandse letterkunde, speciaal in het onderwijs (Amsterdam: Amsterdamse Historische Reeks, [2004]).

U. Vogl, 'Standard Language Ideology and the History of Romance-Germanic Encounters', Past, Present and Future of a Language Border: Germanic-Romance Encounters in the Low Countries, ed. by C. Peersman, G. Rutten \& R. Vosters (Berlin \& New York: De Gruyter, 2015), pp. 61-87.

M. van derWal, 'Grotius' taalbeschouwing in contemporaine context', Nederlandse Taalkunde, 1 (1997), 14-34.

M. van der Wal \& C. van Bree, Geschiedenis van het Nederlands (Houten: Spectrum, 2008).

P. Weiland, Nederduitsche spraakkunst (Amsterdam: Johannes Allart, 1805).

E.M. Wiskerke, De waardering voor de zeventiende-eeuwse literatuur tussen 178 o en 1813 (Hilversum: Verloren, 1995).

\section{About the Author}

Gijsbert Rutten (1977) is a Senior Researcher in Historical Sociolinguistics and a University Lecturer of Dutch Historical Linguistics at the Leiden University Centre for Linguistics. He leads the research project Going Dutch. The Construction of Dutch in Policy, Practice and Discourse, 1750-1850, funded by the Netherlands Organisation for Scientific Research. 